\title{
Pathological changes and bacteriological assessments in the urinary tract of pregnant goats experimentally infected with Brucella melitensis
}

\author{
M. Mazlina ${ }^{1,2}$, S. Khairani-Bejo ${ }^{2}$, H. Hazilawati ${ }^{2}$, T. Tiagarahan ${ }^{3}$, N. N. Shaqinah ${ }^{1}$ and M. Zamri-Saad ${ }^{1,4^{*}}$ (1)
}

\begin{abstract}
Background: This study was conducted to investigate the pathological changes and distribution of $B$. melitensis in the urinary tract of pregnant goats following acute experimental infection. Six Jamnapari crossbred does in their third trimester of pregnancy were randomly assigned into two groups; Group 1 was uninfected control and Group 2 was inoculated conjunctival with $0.1 \mathrm{~mL}$ of the inoculums containing $10^{9} \mathrm{cfu} / \mathrm{mL}$ of live $B$. melitensis. All does were sacrificed 30 days post-inoculation before the kidney, ureter, urinary bladder, urethra and vaginal swab were collected for isolation of B. melitensis. The same tissue samples were fixed in 10\% neutral buffered formalin for hematoxylin and eosin, and immunoperoxidase staining.
\end{abstract}

Results: None of the goats showed clinical signs or gross lesions. The most consistent histopathology finding was the infiltration of mononuclear cells, chiefly the macrophages with few lymphocytes and occasionally neutrophils in all organs along the urinary tract of the infected goats of Group 2. Other histopathology findings included mild necrosis of the epithelial cells of the renal tubules, congestion and occasional haemorrhages in the various tissues. Kidneys showed the most severe lesions. Immunoperoxidase staining revealed the presence of $B$. melitensis within the infiltrating macrophages and the epithelium of renal tubules, ureter, urethra and urinary bladder. Most extensive distribution was observed in the urinary bladder. Brucella melitensis was successfully isolated at low concentration (3. $\left.4 \times 10^{3} \mathrm{cfu} / \mathrm{g}\right)$ in the various organs of the urinary tract and at high concentration $\left(2.4 \times 10^{8} \mathrm{cfu} / \mathrm{mL}\right)$ in the vaginal swabs of all infected goats. Although B. melitensis was successfully isolated from the various organs of the urinary tract, it was not isolated from the urine samples that were collected from the urinary bladder at necropsy.

Conclusion: This study demonstrates the presence of low concentrations of $B$. melitensis in the organs of urinary tract of pregnant does, resulting in mild histopathology lesions. However, B. melitensis was not isolated from the urine that was collected from the urinary bladder.

Keywords: Histopathology, Immunoperoxidase, Brucella melitensis, Urinary tract, Goats

\section{Background}

Brucellosis is a zoonotic disease that causes chronic debilitating disease in humans and major economic losses to livestock farmers $[1,2]$. Caprine brucellosis is caused by Brucella melitensis, which has been recognized as the

\footnotetext{
* Correspondence: mzamri@upm.edu.my

${ }^{1}$ Research Centre for Ruminant Diseases, Faculty of Veterinary Medicine,

Universiti Putra Malaysia, 43400 Serdang, Selangor, Malaysia

${ }^{4}$ Department of Veterinary Laboratory Diagnosis, Faculty of Veterinary

Medicine, Universiti Putra Malaysia, 43400 Serdang, Malaysia

Full list of author information is available at the end of the article
}

most pathogenic species of the Genus Brucella. It is least host-specific and is associated with most cases of human brucellosis [3]. As an intracellular parasite, the bacterium is able to manipulate the host's immune system and flourishes within the professional and non-professional phagocytic cells. Thus, it can replicate within these cells since it is protected from the humoral antibodies and antibiotic treatments $[4,5]$.

In some cases, infected goats and sheep appear healthy with no apparent clinical sign but usually become

(c) The Author(s). 2018 Open Access This article is distributed under the terms of the Creative Commons Attribution 4.0 International License (http://creativecommons.org/licenses/by/4.0/), which permits unrestricted use, distribution, and 
lifelong carriers that disseminate the disease [6]. Accurate detection followed by successful removal of carriers and infected animals are imperative to reduce the cases of brucellosis [6-8].

Brucellosis in animals has always been associated with the disorders of the reproductive and reticulo-endothelial systems [5] causing abortion and enlarged spleen and liver $[1,9,10]$ and less frequently affecting the musculo-nervous systems $[10,11]$. Brucella-induced urinary tract infection is considered extremely rare in animals and humans [12]. To the best of our knowledge, no comprehensive study was done to assess the lesions in the urinary system of female goats following infection with $B$. melitensis. Thus, this study was aimed at determining the distribution of $B$. melitensis and the associated lesions in the urinary tract of does following acute experimental infection with $B$. melitensis in the third trimester of pregnancy.

\section{Methods}

\section{Bacterial inoculums}

A local strain of $B$. melitensis that was isolated from an outbreak of caprine brucellosis in Malaysia was used in this study [13]. The isolate was cultured onto Brucella Agar $\left(\mathrm{BBL}^{\mathrm{rm}}, \mathrm{UK}\right)$ for 4 days at $37{ }^{\circ} \mathrm{C}$ and later transferred into Brucella broth $\left(\mathrm{BBL}^{\mathrm{Tm}}, \mathrm{UK}\right)$ and was further incubated at $37{ }^{\circ} \mathrm{C}$ for another 4 days in an orbital shaker incubator (YIH-DER LM-510, Taiwan). The bacterial cells were then harvested following a series of washing with sterile PBS ( $\mathrm{pH} 7.4)$ and centrifugation at $5,000 \times g, 4{ }^{\circ} \mathrm{C}$ for $10 \mathrm{~min}$ each cycle. The final pellet was then diluted in sterile PBS to a final bacterial concentration of $10^{9}$ cells $/ \mathrm{mL}$ using McFarland's Standard.

\section{Preparation of hyperimmune serum against Brucella melitensis}

The local strain of $B$. melitensis was grown in $35 \mathrm{~mL}$ of Brucella broth $\left(\mathrm{BBL}^{\mathrm{TM}}, \mathrm{UK}\right)$ in shaking incubator for 4 days at $37{ }^{\circ} \mathrm{C}$. The bacterial concentration in the broth was determined using the standard total plate count method. The cells were re-suspended in sterile PBS to obtain a final concentration of $1 \times 10^{9} \mathrm{cfu} / \mathrm{mL}$, were then killed by adding $0.5 \%$ formalin and were emulsified with Freund's complete adjuvant (FCA) (Sigma-Aldrich, US) at $1: 1$ ratio. One $\mathrm{mL}$ of the emulsion was injected subcutaneously into rabbits. Booster doses of the emulsified inoculums, prepared using Freund's incomplete adjuvant (FIA) (Sigma-Aldrich, US) were injected on days 14 and 21. Finally, the hyperimmune serum was harvested at 28 days post-inoculation. The Institutional Animal Care and Use Committee (IACUC) of Universiti Putra Malaysia approved this protocol (AUP No: R019/2014).

\section{Animals and management}

A total of 6 clinically healthy Jamnapari crossbred does of about 3-4 months pregnant were obtained from a farm with no history of brucellosis. They were subjected to the Rose Bengal Plate test (RBPT) and Complement Fixation test (CFT) to ensure the brucellosis-free status. The goats were then divided equally into 2 groups; the uninfected control (Group 1) and the infected (Group 2) groups. Does of Group 1 were exposed to $100 \mu \mathrm{L}$ of sterile PBS via the conjunctiva sac. On the other hand, does of Group 2 were similarly exposed to $100 \mu \mathrm{L}$ of the inoculums containing $10^{9} \mathrm{cfu} / \mathrm{mL}$ of live $B$. melitensis. The infected does were kept entirely in a restricted and isolated housing facility while the control goats were kept separately in a raised house with slatted floor. All does were fed with Napier grass and supplemented with palm kernel cake at the rate of $400 \mathrm{~g} /$ animal/day while drinking water was available ad libitum.

Following the infection, the does were monitored twice daily for clinical signs especially abortion before they were euthanized 30 days post-inoculation. All euthanasia were carried out in an isolated area at a government slaughter house using the standard electrical stunning and exsanguinations protocol, where animals were unconscious following the stunning prior to exsanguination. Post-mortem was carried out immediately and the various sections of the urinary tract encompassing the kidneys, ureter, urinary bladder, urethra, urine and vaginal swabs were collected for bacterial isolation and identification, and for histopathology examination and immunoperoxidase staining. At the same time, urine samples were collected from the urinary bladder into a sterile bottle for bacteriological isolation. For comparison, the uterus and vaginal swabs were also collected and subjected to the same process. The Institutional Animal Care and Use Committee (IACUC) of Universiti Putra Malaysia approved this study (AUP No: R019/2014).

\section{Histopathology}

The formalin-fixed samples were processed in tissue processor (Leica TP 1020, Germany) and Tissue Embedding Console System (Leica EG1150) before they were embedded in paraffin wax and sectioned using the rotary microtome (Leica Jung Multicut 2045, Germany) at $4 \mu \mathrm{m}$ thick. The mounted tissue sections were stained with Harris' haematoxylin and eosin (HE). The slides were viewed under light microscope (Nikon Eclipse 50i, Japan) installed with Nikon imaging software (NIS-Elements D 3.2, Japan). The histological changes were noted and scored as 0: none, 1: 30\% affected, 2: 30-60\% affected and 3: > more than $60 \%$ affected [3]. All evaluations were duplicated and 5 microscopic fields of each slide were randomly selected for lesion scoring. The 
scores were reported as the average value of each lesion and average value for overall scoring.

\section{Immunoperoxidase staining}

The formalin-fixed, paraffin-embedded sections were fixed on Poly-L-Lysine (Sigma- Aldrich, USA) coated microscope slides. Then they were subjected to deparaffinization and rehydration before antigen retrieval was done in citrate buffer for $10 \mathrm{~min}$. Indigenous peroxidase was inactivated using 3\% hydrogen peroxide followed by protein block with $5 \%$ bovine serum albumin for $15 \mathrm{~min}$. Rabbit hyperimmune serum was used as the primary antibody at 1:100 dilution, incubated overnight at $4{ }^{\circ} \mathrm{C}$. Then, secondary antibody, the goat anti-rabbit IgG (Abnova, Taiwan) diluted to 1:500 was poured and incubated for $30 \mathrm{~min}$ at $37^{\circ} \mathrm{C}$. All slides were developed with DAB Chromogen (Dako, USA) and counterstained with Harris' haematoxylin, dehydrated and mounted. Control sections used normal rabbit serum as primary antibody. The slides were viewed under light microscope (Nikon Eclipse 50i, Japan), which was installed with Nikon imaging software (NIS-Elements D 3.2, Japan). The presence and distribution of IP staining were scored as 0: none, 1: focal, 2: multifocal and 3: diffuse [14]. All evaluations were done in duplicate and 5 microscopic fields were randomly selected for lesion scoring. The scores were recorded as average value of each distribution and intensity.

\section{Bacterial isolation from tissues}

The tissue samples were flamed and then placed into sterile zipper plastic bags to minimize contamination. Then, sterile PBS (pH 7.4) was added into the zipper bag at tissue to PBS ratio of 1:2. The samples were then pounded using mortar and pestle. The resultant mixture was used for bacterial culture and extraction of bacterial DNA. The urine samples $(4-5 \mathrm{~mL})$ were collected using needle and syringe into a sterile tube and immediately transported to the laboratory. About $10 \mu \mathrm{L}$ of the tissue mixture and urine sample was cultured onto Brucella agar that was pre-added with Brucella Selective Supplement (Oxoid, England) and incubated at $37{ }^{\circ} \mathrm{C}$ for 10 days. Bacterial colonies that appeared small, rounded, smooth and translucent, glistening and bluish were highly suggestive of $B$. melitensis [11] and were confirmed using PCR. The results were presented as percentage (\%) of positive samples over total number of samples.

\section{Bacterial DNA extraction}

The bacterial DNA was extracted according to the manufacturer's recommendations (NucleoSpin ${ }^{\bullet}$ Tissue DNA Purification Kit, Macherey-Nagel, German). The extraction was initiated by adding $75 \mu \mathrm{L}$ of the processed tissue with $25 \mu \mathrm{L}$ of Proteinase $\mathrm{K}$ solution and $180 \mu \mathrm{L}$ of lysis buffer (Buffer T1) followed by rigorous vortex before incubation at $56{ }^{\circ} \mathrm{C}$ for $3 \mathrm{~h}$ to lyse the samples. The mixture was vortexed regularly during the incubation period. Then, $200 \mu \mathrm{L}$ of Buffer B3 (Lysis buffer) was added, vortexed and incubated at $70{ }^{\circ} \mathrm{C}$ for $10 \mathrm{~min}$. This was followed by adding $210 \mu \mathrm{L}$ of absolute ethanol into the mixture and vortexed. The solution was transferred into tissue columns in collecting tubes and centrifuged for $1 \mathrm{~min}$ at $11,000 \times \mathrm{g}$. The flow-through was discarded before the silica gel within the tissue column was washed twice; first by adding $500 \mu \mathrm{L}$ of Buffer BW followed by centrifugation and later $600 \mu \mathrm{L}$ of Buffer B5. Then, the mixture was centrifuged at $11,000 \times g$ for $2 \mathrm{~min}$ to remove residual ethanol. The tissue columns were transferred into $1.5 \mathrm{~mL}$ micro-centrifuge tubes and $100 \mu \mathrm{L}$ of pre-warmed $70{ }^{\circ} \mathrm{C}$ of Buffer BE was added and left at room temperature for $1 \mathrm{~min}$. The elution containing highly pure DNA was obtained following centrifugation at $11,000 \times g$ for $1 \mathrm{~min}$. The DNA was stored at $-20{ }^{\circ} \mathrm{C}$ until used.

\section{Polymerase chain reaction}

The bacterial colonies and DNA extracts were used as templates for confirmation of $B$. melitensis using the forward P1 (5'-CATGCGCTATGTCTGGTTAC-3') and P2 (5'-AGTGTTTCGGCTCAGAATAATC-3') primer sequences that amplified the fragment at $252 \mathrm{bp}$ [15]. The PCR was performed in $25 \mu \mathrm{L}$ reaction mixture that contained $2.5 \mu \mathrm{L}$ of $10 \times$ buffer, $3 \mathrm{mM} \mathrm{MgCl} 2,400 \mu \mathrm{M}$ dNTPs, $500 \mathrm{nM}$ of each primer, $1.5 \mathrm{U}$ Taq polymerase (MBI Fermentas, Lithuania) and $1 \mu \mathrm{L}$ of purified DNA or bacterial colony mixed with $1 \mu \mathrm{L}$ of $\mathrm{DNAzol}^{\bullet}$ reagent (Thermo Fisher Scientific, USA). The PCR amplifications were performed in a Master Cycler Pro S (Eppendorf, Germany) in 34 cycles with an initial denaturation at $95{ }^{\circ} \mathrm{C}$ for $2 \mathrm{~min}$ and denaturation step for $1.15 \mathrm{~min}$ at $95{ }^{\circ} \mathrm{C}$. The annealing, extension and final extension phases were set at $57.1{ }^{\circ} \mathrm{C}$ for $2 \mathrm{~min}, 72{ }^{\circ} \mathrm{C}$ for $2 \mathrm{~min}$ and $73{ }^{\circ} \mathrm{C}$ for $5 \mathrm{~min}$, respectively. The PCR products were mixed with $1 \mu \mathrm{L}$ of loading dye and were electrophoresed through $1 \%(w / v)$ agarose gel pre-mixed with RedSafeTM Nucleic Acid Staining solution (INTRON, Korea) in $1 \times \mathrm{TBE}$ at $80 \mathrm{~V}$ (Bio-Rad PowerPacTM Basic, USA) for $45 \mathrm{~min}$. Five $\mu \mathrm{L}$ of $100 \mathrm{bp}$ DNA marker (GeneDireX $^{\oplus}$, Taiwan) was run simultaneously. The bands were documented using the gel documentation software called GeneSnap ${ }^{\oplus}$ UK.

\section{Results}

\section{Histopathology changes and IP staining}

Infected does displayed mild glomerulonephritis with neutrophils, glomerular congestion and mild renal tubular necrosis (Fig. 1a). Haemorrhages and foci of inflammatory reactions were occasionally observed in the interstitium. Immunoperoxidase staining of the kidneys 


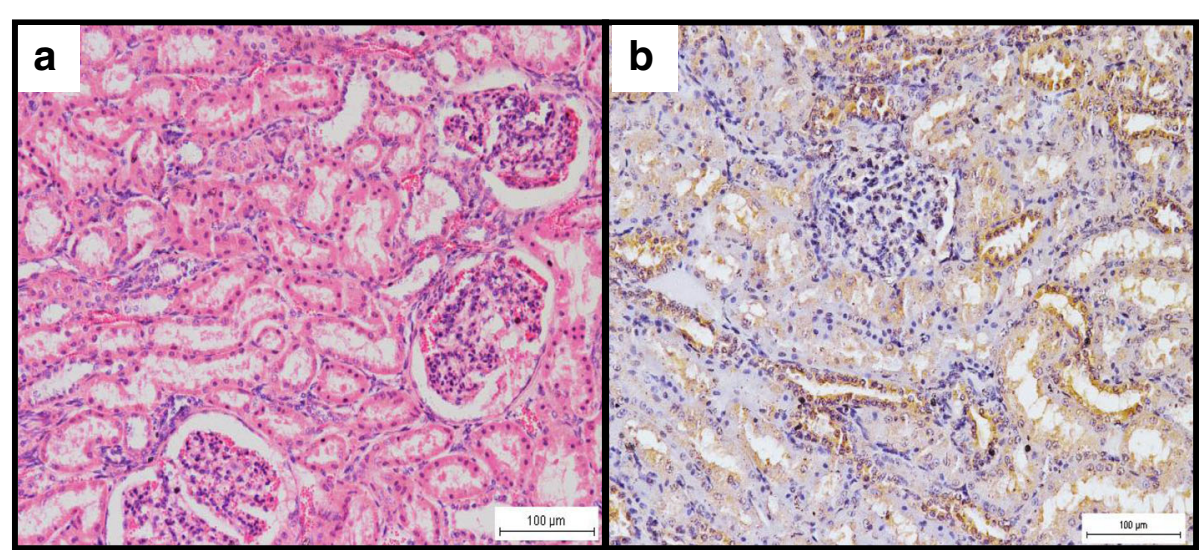

Fig. 1 a Moderate congestion of the glomerulus and mild glomerulonephritis with infiltration of mainly neutrophilic cells. H\&E, $\times 200$. $\mathbf{b}$ Diffuse and moderately strong immunoperoxidase stain reactions in the epithelial cells of the renal tubules and in the cytoplasm of inflammatory cells infiltrating the glomeruli. $I H C, \times 200$

revealed strong to moderate staining (Fig. 1b). Strong reactions were observed in the cytoplasm of the inflammatory cells infiltrating the glomeruli and renal tubules, particularly the distal convoluted and the collecting tubules. Milder immunoreactions were noted in the epithelial cells of the proximal convoluted tubules and occasionally in the lumen of renal tubules. Brucella melitensis was isolated from 3 of the 6 (50\%) kidney samples at an average rate of $3.9 \times 10^{3} \mathrm{cfu} / \mathrm{g}$ of tissue compared to 4 out of $6(66.7 \%)$ kidney samples that were positive PCR (Table 1).

There was also mild inflammation in the ureter (Fig. 2a) with macrophages in the lamina propria and connective tissue stroma. The immunoperoxidase revealed positive staining, particularly within the macrophages and the epithelial cells (Fig. 2b). Again, B. melitensis was successfully isolated from 3 out of $6(50 \%)$ of the ureter samples at the rate of $2.9 \times 10^{3} \mathrm{cfu} / \mathrm{g}$ of tissue compared to 4 out of $6(66.7 \%)$ of the ureter were positive PCR.

All infected does had cystitis, characterised by intense perivascular inflammation with predominantly macrophages (Fig. 3a). The immunoperoxidase staining revealed immunoreactions within the transitional epithelial cells as well as in the cytoplasm of the macrophages (Fig. 3b). The bacterium was isolated from 1 out of 3 (33.3\%) bladder samples at the rate of $4.2 \times 10^{3} \mathrm{cfu} / \mathrm{g}$ of tissue while PCR was $66.7 \%$ (Table 1). Similarly, the urethra of all infected does showed massive infiltration of mainly macrophages at the submucosal and perivascular regions (Fig. 4a). The immunoperoxidase stained the transitional epithelial cells and the cytoplasm of macrophages (Fig. 4b). Attempts to isolate B. melitensis from the urethra yielded 2 out of $3(66.7 \%)$ at an average rate of $2.6 \times 10^{3} \mathrm{cfu} / \mathrm{g}$ of tissue while PCR revealed $100 \%$ positive results. In comparison, $B$. melitensis was isolated from 2 out of 3 (66.7\%) vaginal swab samples at a higher concentration of $2.4 \times 10^{8} \mathrm{cfu} / \mathrm{mL}$ but isolation was unsuccessful from any of the urine sample. The control uninfected goats revealed generally normal histological features with no inflammatory reaction and positive IP staining while B. melitensis was not isolated from any organ.

\section{Lesions and immunoperoxidase scorings}

None of the infected pregnant does of Group 2 exhibited clinical signs following experimental infection. However, 4 kids were eventually delivered weak by the infected does and none survived the first month after birth. Necropsy revealed no obvious gross lesions in the urinary system. Nevertheless, histopathological examinations revealed notable microscopic changes and immunoperoxidase staining in various sections of the urinary tract of the infected goats of Group 2 (Table 2). The average

Table 1 Rate of isolation and average concentration of Brucella melitensis in the various organs of the urinary tract of pregnant goats following acute infection

\begin{tabular}{|c|c|c|c|c|c|}
\hline Group/Organs & Kidneys & Ureter & Urinary Bladder & Urethra & Average \\
\hline G1 & $0 / 6(0 \%)$ & 0/6 (0\%) & 0/3 (0\%) & $0 / 3(0 \%)$ & $0 \%$ \\
\hline \multirow[t]{2}{*}{ G2 } & $3 / 6(50 \%)$ & $3 / 6(50 \%)$ & 1/3 (33\%) & 2/3 (67\%) & $50 \%$ \\
\hline & {$\left[3.9 \times 10^{3}\right]^{\mathrm{a}}$} & $\left.2.9 \times 10^{3}\right]^{a}$ & {$\left[4.2 \times 10^{3}\right]^{a}$} & {$\left[2.6 \times 10^{3}\right]^{a}$} & {$\left[3.4 \times 10^{3}\right]^{a}$} \\
\hline
\end{tabular}

${ }^{\mathrm{a}}$ unit $=\mathrm{cfu} / \mathrm{g}$ tissue 


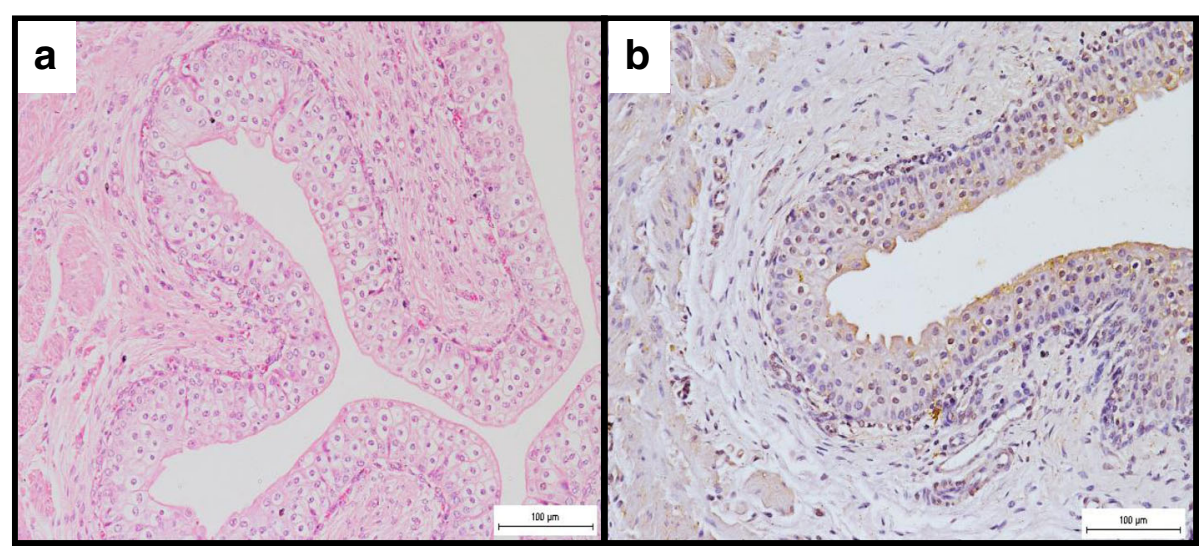

Fig. 2 a Mild congestion and ureteritis characterized by infiltration of macrophages in the connective tissue stroma. H\&E, $\times 200$. $\mathbf{b}$ Positive immunoperoxidase stain reactions in the cytoplasm of the epithelial cells of the ureter and within the infiltrating macrophages. $1 \mathrm{HC}, \times 200$

lesion score for kidney was significantly $(p<0.05)$ higher (score $0.61 \pm 0.28$ ) than the urinary bladder (score 0.31 \pm 0.15 ). However, the immunoperoxidase staining was significantly $(p<0.05)$ higher in the urinary bladder (score $2.01 \pm 0.07$ ) than the kidneys (score $1.33 \pm 0.13$ ) and gradually but significantly $(p<0.05)$ decreasing from urinary bladder to the urethra. The uterus of the infected goats showed significantly $(p<0.05)$ most severe histological lesions but IP distribution score was similar $(p>0.05)$ to those of urinary bladder (Table 2). None of the control uninfected goats of Group 1 showed clinical signs, gross and histopathological changes, and immunoperoxidase staining.

\section{Discussion}

There is a lack of information describing the pathological lesions and distribution of $B$. melitensis in the urinary tract of goats. This study revealed that the most common infiltrating inflammatory cell in the organs of urinary tract is the macrophage [16] while $B$. melitensis was present mostly within the cytoplasm of these macrophages. These are in agreement with earlier studies involving other organs, particularly organs of the reproductive tract $[3,14,17]$. Studies on $B$. abortus have reported its ability to reside and replicate in the macrophages [18] while hiding from the humoral immune responses and the effects of antibiotic treatments [5]. More importantly, the bacterium manipulates the macrophages by turning them into reluctant factory for massive replication of Brucella [19]. Apart from that, macrophages are unwilling agents of dispersal, responsible for the widespread dissemination of the bacterium $[3,20]$. Furthermore, this study has proven that B. melitensis can invade non-phagocytic cells such as the epithelial and fibroblast cells [18, 21].

Brucella melitensis has been detected in the kidneys of West African Dwarf goats where the antigen was found mostly in the epithelium of renal tubules and glomeruli [14]. Similarly, B. ovis was successfully cultured from the kidneys and the urinary bladder of infected stags [15].

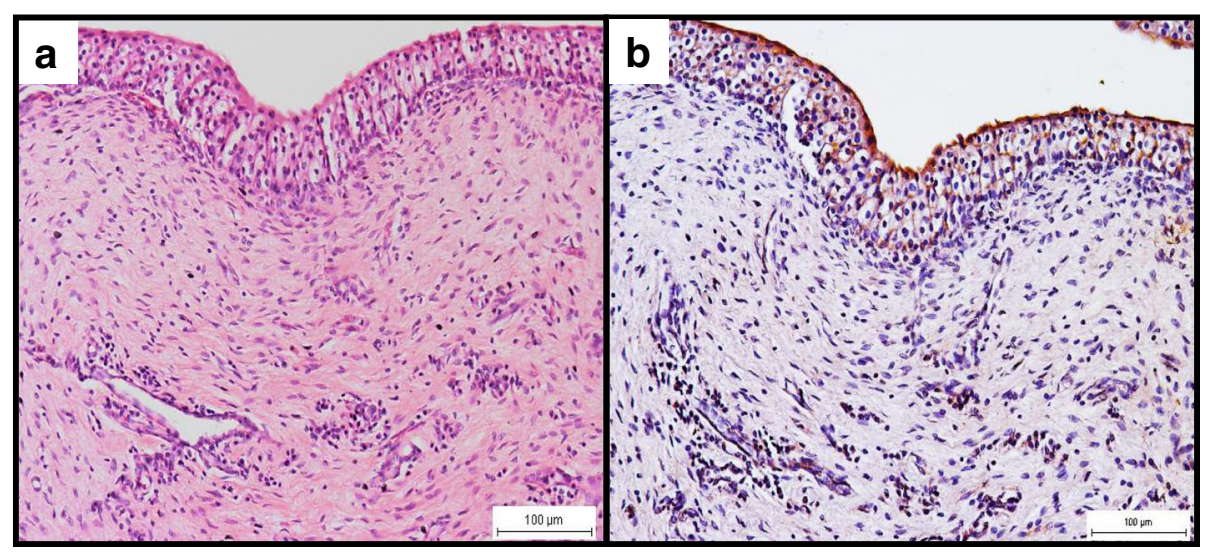

Fig. 3 a Cystitis with macrophages and few lymphocytes in the connective tissue layer of the urinary bladder. H\&E, $\times 200$. b Strong golden brown immunoperoxidase staining observed intracellularly in macrophages and in the transitional epithelial cells of the urinary bladder. IP, $\times 200$ 


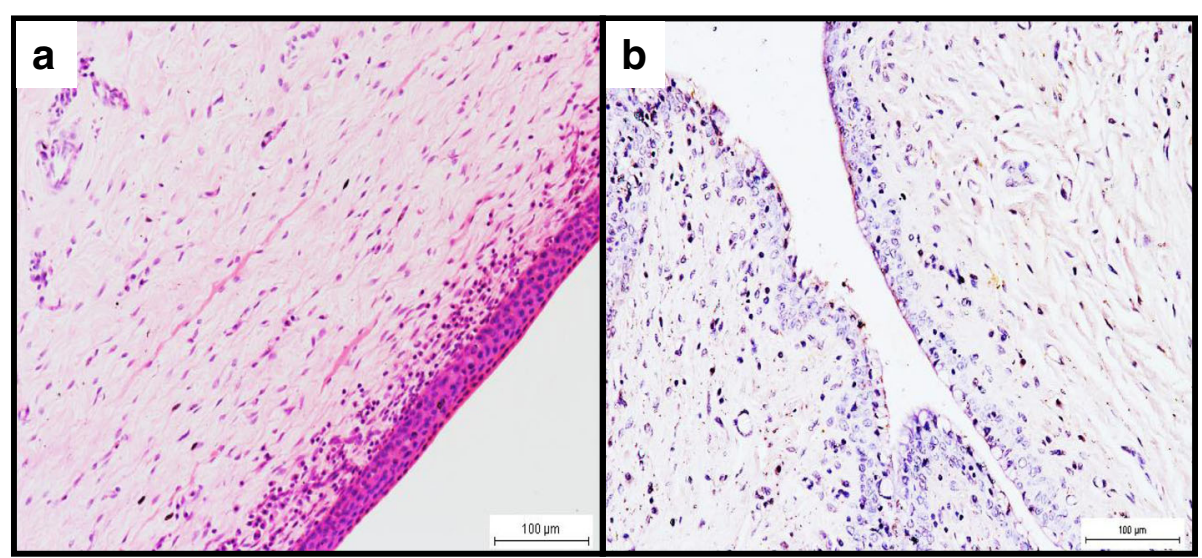

Fig. 4 a Infiltration of few macrophages at the perivascular area and the submucosa of urethra. $H \& E_{1} \times 100$. $\mathbf{b}$ Positive light golden brown immunoperoxidase staining observed in the cytoplasm of the macrophages and epithelial cells of the urethra. IP, $\times 100$

However, both reports did not mention the presence of Brucella in the urine. Furthermore, the concentrations of $B$. melitensis isolated from the various organs of the urinary tract in this study were relatively low compared to the reproductive tract. This might be the reason for the absence of $B$. melitensis in urine. Furthermore, immunoperoxidase staining revealed positive staining within the macrophages and relatively mild stain in the urinary epithelial cells. Therefore, the low level of $B$. melitensis within the epithelial cells of urinary tract was not enough to be excreted into the urine although excretion of Brucella in urine of infected animals has been occasionally reported [22]. Similar involvement of human urinary tract in brucellosis has been reported but the involvement is considered rare and almost always occur together with the reproductive system [12, 23].

Immunoperoxidase staining is a tool for detection of B. melitensis in tissues. It is highly specific and capable of showing the distribution of Brucella in affected tissues [3]. Using immunoperoxidase, B. melitensis has been shown to have tropism for the macrophages and the epithelial cells of urinary tract. Furthermore, polymerase

Table 2 Average histopathology and immunoperoxidase scores (mean $\pm \mathrm{SE}$ ) in the various ogans of the urinary tract of pregnant goats following acute experimental infection with B. melitensis

\begin{tabular}{lll}
\hline Organ & $\begin{array}{l}\text { Histology Score } \\
(\text { Mean } \pm \text { SE })\end{array}$ & $\begin{array}{l}\text { IP Score } \\
(\text { Mean } \pm \text { SE) }\end{array}$ \\
\hline Kidney & $0.61 \pm 0.28^{\mathrm{a}}$ & $1.33 \pm 0.13^{\mathrm{a}}$ \\
Ureter & $0.21 \pm 0.15^{\mathrm{b}}$ & $0.47 \pm 0.18^{\mathrm{c}}$ \\
Urinary bladder & $0.31 \pm 0.15^{\mathrm{b}}$ & $2.00 \pm 0.07^{\mathrm{b}}$ \\
Urethra & $0.21 \pm 0.68^{\mathrm{b}}$ & $0.13 \pm 0.07^{\mathrm{d}}$ \\
Uterus & $0.84 \pm 0.33^{\mathrm{c}}$ & $1.80 \pm 0.42^{\mathrm{c}}$ \\
\hline
\end{tabular}

a,b,c,d Different superscripts represent significant $(p<0.05)$ difference of data within the respective column chain reaction (PCR) has been used lately for antigen detection in infected tissues with high specificity and sensitivity [15, 22, 24]. Nevertheless, bacterial isolation is still the irrefutable method to confirm the presence of the pathogen thus, considered the gold standard for diagnosis of brucellosis [10, 24, 25]. Our attempts to isolate $B$. melitensis from the various organs of the urinary tracts were successful while PCR is deemed useful in detecting nucleic acid fragments of the bacterium [15, 22, 24, 25].

\section{Conclusions}

In conclusion, acute infection of pregnant goats by $B$. melitensis in this study led to mild lesions in the organs of the urinary tract. Low concentrations of $B$. melitensis were found within the macrophage and epithelial cells. However, it was not isolated from the urine samples that were collected from infected urinary bladder.

\section{Abbreviations}

CFT: Complement fixation test; cfu/g: Colony-forming unit per gram; cfu/ L: Colony-forming unit per litre; DAB: 3.3'-Diaminobenzidine;

DNA: Deoxyribonucleic acid; FCA: Freund's complete adjuvant; FIA: Freund's incomplete adjuvant; HE: Haematoxylin and eosin; IACUC: Institutional Animal Care and Use Committee; IgG: Immunoglobulin G; IP: Immunoperoxidase; PBS: Phosphate buffered saline; PCR: Polymerase chain reaction; RBPT: Rose Bengal Plate Test

\section{Acknowledgements}

The authors would like to thank Dr. Annas Salleh, Dr. Nur Adza Rina Mohd Nordi, Mrs. Latifah Hanan and Mrs. Jamilah Jahari of the Histopathology Laboratory, Faculty of Veterinary Medicine, Universiti Putra Malaysia for their technical assistance.

\section{Funding}

The FRGS Grant 07-03-11-1026FR of the Ministry of Higher Education Malaysia and the Universiti Putra Malaysia IPS Grant 9468500 funded the study.

\section{Availability of data and materials}

The datasets during and/or analysed during the current study are available from the first author on reasonable request. 


\section{Authors' contributions}

MM and NNS collected and analysed data, and drafting of manuscript. SKB and $\mathrm{HH}$ designed the experiment and revised manuscript. $\Pi \pi$ revised the manuscript. MZS designed experiment, analysed data and revised manuscript. All authors read and approved the final manuscript.

\section{Ethics approval}

The experiment was approved by the Institutional Animal Care and Use Committee, Universiti Putra Malaysia (IACUC no. R019/2014).

\section{Consent for publication}

Not applicable.

\section{Competing interests}

The authors declare that they have no competing interests.

\section{Publisher's Note}

Springer Nature remains neutral with regard to jurisdictional claims in published maps and institutional affiliations.

\section{Author details}

${ }^{1}$ Research Centre for Ruminant Diseases, Faculty of Veterinary Medicine Universiti Putra Malaysia, 43400 Serdang, Selangor, Malaysia. ²Department of Veterinary Pathology \& Microbiology, Faculty of Veterinary Medicine, Universiti Putra Malaysia, 43400 Serdang, Selangor, Malaysia. ${ }^{3}$ Puncak Jalil Veterinary Clinic, Taman Puncak Jalil, 43300 Seri Kembangan, Seri Kembangan, Selangor, Malaysia. ${ }^{4}$ Department of Veterinary Laboratory Diagnosis, Faculty of Veterinary Medicine, Universiti Putra Malaysia, 43400 Serdang, Malaysia

Received: 31 January 2017 Accepted: 19 June 2018

Published online: 25 June 2018

\section{References}

1. Seleem MN, Boyle SM, Sriraganathan N. Brucellosis: a re-emerging zoonosis. Vet Microbiol. 2010;140:392-8.

2. Bamaiyi PH, Hassan L, Khairani-Bejo S, ZainalAbidin M, Ramlan M, Adzhar A. Prevalence and distribution of Brucella melitensis in goats in Malaysia from 2000 to 2009. Prev Vet Med. 2015;119:232-6.

3. Xavier MN, Paixao TA, den Hartigh AB, Tsolis RM, Santos RL. Pathogenesis of Brucella spp. Open Vet Sci J. 2010;4:109-18.

4. Celli J. Surviving inside a macrophage: the many ways of Brucella. Res Microbiol. 2006;157:93-8.

5. Christopher S, Umapathy BL, Ravikumar KL. Brucellosis: review on the recent trends in pathogenicity and laboratory diagnosis. J Lab Phys. 2010;2:55-60.

6. Corbel MJ. Brucellosis in humans and animals. World Health Organization. 2006; http://www.who.int/csr/resources/publications/Brucellosis.pdf.

7. Kahl-McDonagh MM, Ficht TA. Evaluation of protection afforded by Brucella abortus and Brucella melitensis unmarked deletion mutants exhibiting different rates of clearance in BALB/c mice. Infect Immun. 2006;74:4048-57.

8. Gorvel JP. Brucella: a Mr "Hide" converted into Dr Jekyll. Microb Infect. 2008; 10:1010-3.

9. Traxler RM, Lehman MW, Bosserman EA, Guerra MA, Smith TL. A literature review of laboratory-acquired brucellosis. J Clin Microbiol. 2013;51:3055-62.

10. Bamaiyi PH, Hassan L, Khairani-Bejo S, Zainal Abidin M. Updates on brucellosis in Malaysia and Southeast Asia. Malaysian J Vet Res. 2014;5:71-82.

11. OiE. Bovine 355 brucellosis. OiE terrestrial manual; 2009. http://www.oie.int/ fileadmin/Home/eng/Health_standards/tahm/2008/pdf/2.04.03_BOVINE_ BRUCELL.pdf.

12. Stamatiou K, Polyzois K, Dahanis S, Lambou T, Skolarikos A. Brucella melitensis: a rarely suspected cause of infections of genitalia and the lower urinary tract. Braz J Infect Dis. 2009;13:86-9.

13. Plumeriastuti $\mathrm{H}$, Zamri-Saad M. Detection of Brucella melitensis in seropositive goats. Online J Vet Res. 2012;16:1-7.

14. Emikpe BO, Sabri MY, Ezeasor CK, Tanko PN. Immunohistochemical detection of Brucella mellitensis and Coxiella burnetii antigens in formalinfixed tissues of west African dwarf goats. Arch Clin Microbiol. 2013;4 https:// doi.org/10.3823/270.

15. Ridler AL, West DM, Collett MG. Pathology of Brucella ovis infection in red deer stags (Cdervus elaphus). NZ Vet J. 2012;60:146-9.
16. Ahmed MO, Elmeshri SE, Abuzweda AR, Blauo M, Abouzeed YM, Ibrahim A, Salem H, Alzwam F, Abid S, Elfahem A, Elrais A. Seroprevalence of brucellosis in animals and human populations in the western mountains region in Libya, December 2006-January 2008. Eurosurveillance. 2010; 15: pii:19625. Available online: http://www.eurosurveillance.org/NiewArticle. aspx?Articleld=19625.

17. Grilló MJ, Blasco JM, Gorvel JP, Moriyón I, Moreno 380 E. What have we learned from brucellosis in the mouse model? Vet Res. 2012;43 https://doi. org/10.1186/1297-9716-43-29.

18. Vitry MA, Hanot Mambres D, Deghelt M, Hack K, Machelart A, Lhomme F, Vanderwinden JM, Vermeersch M, De Trez C, Pérez-Morga D, Letesson JJ, Muraille E. Brucella melitensis invades murine erythrocytes during infection. Infect Immun. 2014;82:3927-2938.

19. Poester FP, Nielsen K, Samartino LE, Yu WL. Diagnosis of brucellosis. Open Vet Sci J. 2010:4:46-60.

20. von Bargen K, Gorvel JP, Salcedo SP. Internal affairs: investigating the Brucella intracellular lifestyle. FEMS Microbiol Rev. 2012;36:533-62.

21. He Y. Analyses of Brucella pathogenesis, host immunity, and vaccine targets using systems biology and bioinformatics. Frontiers Cell Infect Microbiol. $2012 \cdot 2 \cdot 2$

22. Moshkelani S, Javaheri-Koupaei M, Rabiee S, Moazeni M. Detection of Brucella spp. and Leptospira spp. by multiplex polymerase chain reaction (PCR) from aborted bovine, ovine and caprine fetuses in Iran. Afr J Microbiol Res. 2011:5:4627-30.

23. Uncu H, Demiroğlu YZ, Gül U, Güvel S, Turunç T, Cokaloğlu S, Arslan H. A case of brucellosis presenting with urinary tract infection. Mikrobiyologi Bulteni. 2006;40:275-8.

24. Smirnova EA, Vasin AV, Sandybaev NT, Klotchenko SA, Plotnikova MA, Chervyakova OV, Sansyzbay AR, Kiselev OI. Current methods of human and animal brucellosis diagnostics. Adv Infect Dis. 2013;3:177-84.

25. Yu WL, Nielsen K. Review of detection of Brucella sp. by polymerase chain reaction. Croatian Medic J. 2010;51:306-13.

\section{Ready to submit your research? Choose BMC and benefit from:}

- fast, convenient online submission

- thorough peer review by experienced researchers in your field

- rapid publication on acceptance

- support for research data, including large and complex data types

- gold Open Access which fosters wider collaboration and increased citations

- maximum visibility for your research: over $100 \mathrm{M}$ website views per year

At BMC, research is always in progress.

Learn more biomedcentral.com/submissions 